Zeszyty Naukowe Szkoły Głównej Gospodarstwa Wiejskiego

Ekonomika i Organizacja Gospodarki Żywnościowej nr 115, 2016: 5-21

\title{
Marian Podstawka
}

Wydział Nauk Ekonomicznych

Szkoła Główna Gospodarstwa Wiejskiego w Warszawie

\section{Agnieszka Deresz}

Urząd Skarbowy w Siedlcach

\section{Ocena skutków zmian dotyczących stosowania kosztów uzyskania przychodów przez twórców, artystów, pracowników naukowych i dziennikarzy}

\section{Wstęp}

Do końca 2012 roku całość przychodów twórców, artystów, naukowców czy dziennikarzy z praw autorskich i praw pokrewnych objęta była bardzo korzystnymi 50-procentowymi kosztami uzyskania przychodu, które nie były ograniczone żadnym limitem kwotowym. Oznaczało to, że podatek dochodowy od osób fizycznych był płacony tylko od połowy uzyskanych przychodów z ww. praw. Od 1 stycznia 2013 roku w związku z nowelizacją ustawy o podatku dochodowym od osób fizycznych weszły w życie zmiany dotyczące 50-procentowych kosztów uzyskania przychodu ${ }^{1}$. W wyniku przedmiotowych zmian łączne koszty uzyskania przychodów z praw autorskich i praw pokrewnych - w skali roku podatkowego - nie mogą przekroczyć połowy kwoty stanowiącej górną granicę pierwszego przedziału skali podatkowej, czyli w latach 2013-2015 kwoty 42764 zł (połowa z 85528 zł).

Celem opracowania jest ocena skutków zmian stosowania kosztów uzyskania przychodu przez twórców, artystów, pracowników naukowych i dziennikarzy polegająca na wprowadzeniu limitu kwotowego 42764 zł. Analizą objęto 4-letni okres, od 2012 roku do 2015 roku. Rok 2012 był tym, w którym 50 -procentowe koszty uzyskania przychodu z praw autorskich i praw pokrew-

\footnotetext{
${ }^{1}$ Przedmiotowe zmiany zostały wprowadzone ustawą z dnia 24 października 2012 r. o zmianie podatku dochodowego od osób fizycznych (Dz.U. 2012, poz. 1278).
} 
nych nie były objęte żadnym limitem kwotowym oraz lata 2013-2015, bezpośrednio po wprowadzeniu przedmiotowego ograniczenia kwotowego. Do analizy wykorzystano dane pochodzące z opracowań Ministerstwa Finansów dotyczące rozliczenia podatku dochodowego od osób fizycznych za lata 2012-2013 oraz dane z systemu POLTAX Urzędu Skarbowego w Siedlcach dotyczące rozliczenia podatku dochodowego od osób fizycznych za lata 2012-2015. Opracowanie zawiera również komentarz do wprowadzonych zmian dotyczących stosowania kosztów uzyskania przychodu przez twórców, artystów, pracowników naukowych i dziennikarzy.

W kontekście celu opracowania sformułowano dwie hipotezy badawcze:

- Zmiany dotyczące stosowania kosztów uzyskania przychodów przez twórców, artystów, pracowników naukowych i dziennikarzy spowodują znaczny wzrost opodatkowania ich dochodów.

- Częstotliwość uzyskiwania przychodów z prawa autorskich i praw pokrewnych ma wpływ na stopien ich opodatkowania.

\section{Możliwość zastosowania 50-procentowych kosztów uzyskania przychodu w przypadku praw autorskich i praw pokrewnych}

Pięćdziesięcioprocentowe koszty uzyskania przychodów stosuje się z tytułu:

- zapłaty twórcy za przeniesienie prawa własności wynalazku, topografii układu scalonego, wzoru użytkowego, wzoru przemysłowego, znaku towarowego lub wzoru zdobniczego,

- opłaty licencyjnej za przeniesienie prawa stosowania wynalazku, topografii układu scalonego, wzoru użytkowego, wzoru przemysłowego, znaku towarowego lub wzoru zdobniczego, otrzymanej w pierwszym roku trwania licencji od pierwszej jednostki, z którą zawarto umowę licencyjną,

- korzystania przez twórców z praw autorskich i artystów wykonawców z praw pokrewnych, w rozumieniu odrębnych przepisów, lub rozporządzania przez nich tymi prawami.

Koszty w tej wysokości przysługują bez względu na to, czy podstawą uzyskania przychodu ze wskazanych tytułów jest umowa o pracę, umowa o dzieło, umowa zlecenie, umowa o przeniesienie prawa własności wynalazku czy inna umowa - art. 22 ust. 9 pkt 1-3 ustawy o podatku dochodowym od osób fizycznych z 1991 roku. Przy czym w art. 22 ust. 12 ustawy o podatku dochodowym od osób fizycznych zastrzeżono, że koszty uzyskania przychodów określone $\mathrm{w}$ art. 9 nie mają zastosowania do przychodów, o których mowa w art. 14 ustawy 
o podatku dochodowym od osób fizycznych - a zatem nie mają zastosowania do przychodów z pozarolniczej działalności gospodarczej, o której mowa w art. 10 ust. 1 pkt 13 ustawy o podatku dochodowym od osób fizycznych.

Generalnie koszty uzyskania przychodów z tytułów określonych powyżej ustala się w wysokości $50 \%$ uzyskanego przychodu. Jedynie w przypadku korzystania przez twórców z praw autorskich i artystów wykonawców z praw pokrewnych, w rozumieniu odrębnych przepisów, lub rozporządzania przez nich tymi prawami koszty uzyskania przychodów oblicza się od przychodu pomniejszonego o potrącone przez płatnika $\mathrm{w}$ danym miesiącu składki na ubezpieczenia emerytalne i rentowe oraz na ubezpieczenie chorobowe, o których mowa w art. 26 ust. 1 pkt 2 lit. b ustawy o podatku dochodowym od osób fizycznych, których podstawę stanowi ten przychód.

Aby móc skorzystać z 50-procentowych kosztów uzyskania przychodów w przypadku praw autorskich na podstawie obowiązujących przepisów prawa:

- należy posiadać status twórcy,

- należy posiadać prawa autorskie w rozumieniu odrębnych przepisów,

- należy osiagnąć przychód z wykorzystania praw autorskich lub rozporządzania tymi prawami,

- prawa autorskie lub rozporządzanie tymi prawami nie mogą wynikać z „twórczości” prowadzonej w ramach pozarolniczej działalności gospodarczej,

- należy podlegać nieograniczonemu obowiązkowi podatkowemu jako twórca. W zakresie weryfikacji trzech pierwszych warunków, należy odnieść się do odrębnych przepisów, przede wszystkim do ustawy o prawie autorskim i prawach pokrewnych z 1997 roku.

Prawo do 50-procentowych kosztów uzyskania przychodów przysługuje wyłącznie twórcy. Analiza ustawy o prawie autorskim prowadzi do wniosku, że twórcą jest autor utworu [Radwański red. 2007, s. 67]. Zgodnie z art. 1 ust. 1 ustawy o prawie autorskim przez utwór rozumie się każdy przejaw działalności twórczej o indywidualnym charakterze, ustalony w jakiejkolwiek postaci, niezależnie od wartości, przeznaczenia i sposobu wyrażenia. W szczególności mogą to być m.in. utwory: wyrażone słowem, symbolami matematycznymi, znakami graficznymi (literackie, publicystyczne, naukowe, kartograficzne oraz programy komputerowe); plastyczne; fotograficzne; muzyczne i słowno-muzyczne; sceniczne, sceniczno-muzyczne, choreograficzne i pantomimiczne. Jest to jedynie przykładowy katalog, gdyż definicja utworu zawarta w ustawie o prawie autorskim jest bardzo szeroko i poza ustalonym katalogiem wyłączeń, zawartych $\mathrm{w}$ art. 4 ustawy o prawie autorskim ${ }^{2}$, ogranicza ją jedynie wymóg posiadania

\footnotetext{
${ }^{2}$ Zgodnie $\mathrm{z}$ art. 4 ustawy o prawie autorskim nie stanowią przedmiotu prawa autorskiego: akty normatywne lub ich normatywne projekty, urzędowe dokumenty, materiały, znaki i symbole, opublikowane opisy patentowe lub ochronne, proste informacje prasowe.
} 
cech indywidualnej twórczości. Działalność twórcza o indywidualnym charakterze jest własnością człowieka. Mówiąc inaczej, tylko osoba fizyczna może być twórca. Pozostałe osoby prawa cywilnego takiego przymiotu nie posiadajac ani osoby prawne (np. spółka z ograniczoną odpowiedzialnością ani spółka akcyjna), ani jednostki niemające osobowości prawnej, którym ustawa przyznaje jednak zdolność prawną (np. osobowe spółki prawa handlowego), nie mogą być autorem utworu [Radwański red. 2007, s. 67-68]. Co najwyżej, mogą one nabyć prawa do utworu od twórcy będącego osobą fizyczną. O tym, czy mamy do czynienia z działalnością twórczą o indywidualnym charakterze nie decyduje wola stron ani subiektywne przekonanie o twórczym wkładzie pracy, ale to, czy w konkretnym dziele można obiektywnie wyróżnić cechy związane z niepowtarzalną osobowością człowieka.

Prawa autorskie co do zasady przysługują twórcy ${ }^{3}$, jednak zdarzają się sytuacje, w których prawa autorskie, czy to pierwotnie (na podstawie samej ustawy o prawie autorskim), czy to następczo (na podstawie umowy cywilnoprawnej lub umowy o pracę) przysługują innym niż twórca osobom. Do takich osób, którym przysługują prawa autorskie, ale których za twórcę uznać nie można, jak np. wydawca, producent, pracodawca, którego pracownik stworzył program komputerowy w ramach stosunku pracy, 50-procentowe koszty uzyskania przychodu nie mają zastosowania [Bartosiewicz i Kubacka 2013, s. 656]. Twórca, który wyzbył się już praw autorskich, np. pracownik, który utracił prawa majątkowe do programu komputerowego na rzecz pracodawcy i ponownie zamierza wykorzystać ten utwór poza ochroną prawną przyznawaną przez ustawę o prawie autorskim, również nie może skorzystać z 50-procentowych kosztów uzyskania przychodu.

Przychód z praw autorskich jest wynikiem zawartych przez twórcę umów, których przedmiotem są przysługujące twórcy prawa autorskie. Na gruncie ustawy o prawie autorskim można wyróżnić dwa typy umów: o przeniesienie praw oraz o korzystanie z utworu, zwanych licencjami.

Przychody z tytułu korzystania $\mathrm{z}$ praw autorskich lub rozporządzania tymi prawami mogą być uzyskiwane w ramach różnych źródeł przychodów. Zazwyczaj są one osiagane w ramach stosunku pracy, działalności wykonywanej osobiście, pozarolniczej działalności gospodarczej. Udostępnienie praw autorskich w ramach prowadzenia pozarolniczej działalności gospodarczej wyłącza możliwość zastosowania 50-procentowych kosztów uzyskania przychodów. W przypadku pozostałych źródeł przychodów, stosowanie 50-procentowych kosztów uzyskania przychodu teoretycznie jest możliwe, jednak w praktyce w dużej mierze zależy od charakteru umowy i precyzyjności jej postanowień. W orzecz-

\footnotetext{
${ }^{3}$ Zgodnie $\mathrm{z}$ art. 8 ust. 1 ustawy o prawie autorskim, prawo autorskie przysługuje twórcy, o ile ustawa nie stanowi inaczej.
} 
nictwie, praktyce podatkowej i doktrynie podkreśla się, że w przypadku gdy w ramach zawartej umowy twórca świadczy również prace, które twórczego charakteru nie mają, warunkiem skorzystania z możliwości uwzględnienia 50-procentowych kosztów jest właściwe wyodrębnienie części wynagrodzenia, które jest odpłatnością za udostępnienie praw autorskich [wyrok NSA z 12.03.2010 r., II FSK 17914/08, Wyrok WSA w Warszawie z 3.07.2009 r., III SA/Wa 35/09]. Ma to szczególne znaczenie przy stosunku pracy, w ramach którego z reguły pracownik poza działalnością twórczą wykonuje obowiązki pracownicze. W ocenie sądów administracyjnych, zastosowanie podwyższonych kosztów uzyskania przychodów do całego przychodu uzyskanego przez twórcę ze stosunku pracy jest możliwe tylko, gdy cała praca wykonywana przez pracownika jest związana $\mathrm{z}$ wykonywaniem utworu [Wyrok WSA w Gliwicach z 11.01.2011 r., I SA/G1 781/10, wyrok WSA w Krakowie z 16.02.2010 r. I SA/ $/ \mathrm{Kr} 1454 / 09]$.

\section{Wzrost podatku dochodowego od osób fizycznych po zmianach w 50-procentowych kosztach uzyskania przychodu}

Wprowadzenie od 1 stycznia 2013 roku zmian dotyczących stosowania kosztów uzyskania przychodu oznacza, że limit odliczenia 50\% kosztów uzyskania przychodu zostanie wyczerpany, jeżeli przychód podatnika (z praw autorskich i praw pokrewnych) przekroczy kwotę 85528 zł, czyli przykładowo podatnik, który uzyska w roku podatkowym przychód z tego tytułu w wysokości, np. 100 tys. zł, będzie mógł odliczyć maksymalnie określoną w limicie kwotę 42764 zł. rzedmiotowy limit dotyczy jedynie przychodów, które objęte są 50-procentowymi kosztami uzyskania przychodu. Jeśli podatnik uzyska przykładowo przychód z praw autorskich w wysokości 85528 zł (z wynagrodzenia ze stosunku pracy 55 tys. zł oraz z pozarolniczej działalności gospodarczej 40 tys. zł), to $50 \%$ kosztów ograniczonych limitem 42764 zł zastosuje tylko do przychodów z praw autorskich. Do przychodów z wynagrodzenia ze stosunku pracy zastosuje natomiast ryczałtowe koszty w wysokości ustalonej zgodnie $\mathrm{z}$ art. 22 ust. 2 albo ust. 11 ustawy o podatku dochodowym od osób fizycznych, zaś w przypadku przychodów z pozarolniczej działalności gospodarczej opodatkowanych na zasadach ogólnych przy zastosowaniu skali podatkowej zastosuje koszty, o których mowa w art. 22 ust. 1 ustawy o podatku dochodowym od osób fizycznych. 
Co będzie się działo w sytuacji, gdy np. podatnik uzyskujący przychody $\mathrm{z}$ umowy o dzieło z przeniesieniem praw autorskich ${ }^{4}$ przekroczy limit kosztów, tj. kwotę 42764 zł? Czy będzie miał prawo do zastosowania 20\% kosztów uzyskania przychodu, tj. takich które przysługują podatnikowi uzyskującemu przychody $\mathrm{z}$ umowy o dzieło bez przenoszenia praw autorskich ${ }^{5}$ ? A mianowicie: Koszty uzyskania przychodów z umów o dzieło są określone procentowo. Generalnie wynoszą one $20 \%$ uzyskanego przychodu. Przy czym, jeżeli przedmiotem zawartej umowy jest czynność stanowiąca przedmiot prawa autorskiego, tj. jest to umowa o dzieło z przeniesieniem praw autorskich, wówczas koszty określa się w wysokości $50 \%$ uzyskanego przychodu. Z przepisów ustawy o podatku dochodowym od osób fizycznych nie wynika możliwość zastosowania przez twórcę, artystę, naukowca czy dziennikarza osiągającego przychód z praw autorskich na podstawie umowy o dzieło $20 \%$ kosztów uzyskania przychodu po wyczerpaniu 50\%. Oznacza to, że jeśli przychody tych podatników zatrudnionych w ramach umów o dzieło przenoszących prawa autorskie przekroczą górną granicę pierwszego przedziału skali podatkowej, tj. kwotę 85528 zł, wówczas nie będą miały zastosowania jakiekolwiek koszty uzyskania przychodu. Wynika z tego, że bardziej aktywni podatnicy nie muszą ponosić żadnych kosztów uzyskania przychodu, co jest typowym absurdem podatkowym.

Przykład

Podatnik w kwietniu 2013 roku uzyskał przychód z umowy o dzieło w wysokości 120000 zł, do której mają zastosowanie prawa autorskie. Przy obliczeniu podatku dochodowego od osób fizycznych zastosował 50-procentowe koszty uzyskania przychodów od przychodu w kwocie 85528 zł. Koszty te wyniosły $42764 \mathrm{zl}(85528 \mathrm{zl} \cdot 50 \%)$. Oznacza to, że do przychodu w kwocie $34472 \mathrm{zl}$ (120 $000 \mathrm{zl}-85528 \mathrm{zl})$ nie mają zastosowania żadne koszty uzyskania przychodu. Dochód do opodatkowania wyniesie zatem 77236 zł (120 000 zł-42 764 zł), a należny podatek dochodowy od osób fizycznych za 2013 rok wyniesie 13346 zł (77 $236 \mathrm{zl} \cdot 18 \%-556,02 \mathrm{zl})$.

W sytuacji gdyby nie wprowadzono od 1 stycznia 2013 roku zmian w zasadach stosowania 50-procentowych kosztów uzyskania przychodu, należny podatek dochodowy od osób fizycznych podatnika z przykładu wyniósłby 10244 zł, tj. dochód do opodatkowania $60000 \mathrm{zł}(120000 \mathrm{zl}-50 \% \cdot 120000 \mathrm{zł})$, należny podatek obliczony według skali podatkowej $(60000 \mathrm{zł} \cdot 18 \%-556,02 \mathrm{zł})$. Za-

\footnotetext{
${ }^{4} \mathrm{Z}$ umową o dzieło z przeniesieniem praw autorskich mamy do czynienia w sytuacji, gdy wykonawca coś dla nas „tworzy”, z czego potem będziemy korzystać i chcemy (lub powinniśmy) mieć do tego prawa autorskie.

${ }^{5} \mathrm{Z}$ umową o dzieło bez przeniesienia praw autorskich mamy do czynienia w sytuacji, gdy wykonawca coś dla nas „tworzy” i nie przenosi na nas praw autorskich.
} 
tem na przedmiotowej zmianie w tym konkretnym przypadku podatnik (twórca, artysta, naukowiec czy dziennikarz) stracił $3102 \mathrm{zł}$.

To, ile straci twórca, artysta, naukowiec czy dziennikarz na zmianie od 1 stycznia 2013 roku zasad stosowania kosztów uzyskania przychodu, przedstawiono $\mathrm{w}$ tabeli 1.

Z zawartego w tabeli 1 porównania opodatkowania przychodów uzyskiwanych z tytułu praw autorskich i praw pokrewnych w 2012 roku i w latach 2013-2015 wynika, że podatnicy (twórcy, artyści, naukowcy i dziennikarze) uzyskujący przychód roczny mniejszy niż 85528 zł, nie będą obciążeni większym ciężarem podatkowych pomimo wprowadzonych od 1 stycznia 2013 roku niekorzystnych zmian stosowania kosztów uzyskania przychodu. Wzrost obciążenia podatkowego nastąpi już w stosunku do tej grupy podatników uzyskujących przychód roczny większy od kwoty 85528 zł, np. podatnik uzyskujący przychód roczny w wysokości 90 tys. zł w latach 2013-2015 zapłaci większy podatek należny ${ }^{6}$ o 402 zł, tj. o 5\% w stosunku do 2012 roku, uzyskując tą samą wysokość przychodu. Wysokość podatku należnego do zapłaty wzrasta sukcesywnie w stosunku do wzrostu wysokości przychodów z praw autorskich i praw pokrewnych. Podatnicy, których przychody roczne będą wzrastały od 128293 zł do kwoty 171058 zł, odczują największy wzrost wysokości podatku należnego do zapłaty po wprowadzeniu zmian stosowania kosztów uzyskania przychodu. Podatnik, który w latach 2013-2015 uzyska przychody roczne w wysokości 128293 zł, zapłaci podatek należy większy o 35\% niż w 2012 roku, a podatnik, który uzyska w latach 2013-2015 przychody roczne większe zaledwie o 3707 zł, zapłaci podatek większy o 42\% niż podatnik w 2012 roku, z kolei podatnik, który uzyska w latach 2013-2015 przychody roczne większe o 15707 zł, zapłaci podatek o 60\% większy niż w 2012 roku. Wynika to z tego, iż podatnik, który uzyskał przychód roczny w wysokości 128 293-171 058 zł, w 2012 roku należny podatek dochodowy obliczył według stawki podatkowej $18 \%$ obowiązującej w pierwszym przedziale skali podatkowej ${ }^{7}$, a uzyskanie tego samego przychodu w latach 2013-2015 zobowiązało już podatnika do obliczenia podatku należnego według innej stawki (32\%) obowiązującej w drugim przedziale skali podatkowej $^{8}$. Podatnik uzyskując przychód w skali roku powyżej 171058 zł (zarówno przed wprowadzeniem omawianych zmian w zakresie stosowania kosztów uzy-

\footnotetext{
${ }^{6}$ Podatkiem należnym za dany rok jest podatek dochodowy wynikający z zeznania podatkowego, chyba że właściwy organ podatkowy lub organ kontroli skarbowej wyda decyzję, w której określi inną wysokość podatku. W razie niezłożenia zeznania podatkowego, organ podatkowy wydaje decyzję określającą wysokość zobowiązania w podatku dochodowym.

${ }^{7}$ Przychód: $128293 \mathrm{zl}-50 \%$ kosztów uzyskania przychodu: $64146,50 \mathrm{zł} \approx$ dochód (podstawa opodatkowania): $64147 \mathrm{zł}$, podatek należny: $(64147 \mathrm{zł} \cdot 18 \%)-556,02 \mathrm{zł} \approx 10990 \mathrm{zł}$.

${ }^{8}$ Przychód: 128293 zł - koszty uzyskania przychodu: 42764 zł = dochód (podstawa opodatkowania): 85529 zł, podatek należny: [(85 529 zł - $85528 \mathrm{zl)} \cdot 32 \%]+14839,02 \mathrm{zł} \approx 14839 \mathrm{zł}$.
} 
Tabela 1

Wysokość rocznego podatku należnego z tytułu praw autorskich i praw pokrewnych w latach 2012-2015

\begin{tabular}{|c|c|c|c|c|c|c|}
\hline Lp. & $\begin{array}{l}\text { Miesięczny } \\
\text { przychód } \\
\text { [zł] }\end{array}$ & $\begin{array}{l}\text { Roczny } \\
\text { przychód } \\
\text { [zł] }\end{array}$ & $\begin{array}{c}\text { Roczny } \\
\text { podatek } \\
\text { należny } \\
\text { w } 2012 \text { roku } \\
\text { [zł] }\end{array}$ & $\begin{array}{c}\text { Roczny } \\
\text { podatek } \\
\text { należny } \\
\text { w latach } \\
2013-2015 \\
\text { [zł] }\end{array}$ & $\begin{array}{c}\text { Wzrost } \\
\text { podatku } \\
\text { należnego } \\
{[\%]} \\
(5: 4)\end{array}$ & $\begin{array}{c}\text { Różnica } \\
\text { w kwocie } \\
\text { podatku } \\
\text { należnego do } \\
\text { zapłaty } \\
\text { w latach } \\
2012-2015 \\
\text { [zł] - (5-4) }\end{array}$ \\
\hline 1 & 2 & 3 & 4 & 5 & 6 & 7 \\
\hline 1 & 1000,00 & 12000,00 & $524,00^{*}$ & $524,00^{*}$ & - & - \\
\hline 2 & 5000,00 & 60000,00 & 4844,00 & 4844,00 & - & - \\
\hline 3 & 6000,00 & 72000,00 & 5924,00 & 5924,00 & - & - \\
\hline 4 & 7000,00 & 84000,00 & 7004,00 & 7004,00 & - & - \\
\hline 5 & 7127,33 & 85528,00 & 7142,00 & 7142,00 & - & - \\
\hline 6 & 7130,00 & 85560,00 & 7144,00 & 7147,00 & - & 5,00 \\
\hline 7 & 7500,00 & 90000,00 & 7544,00 & 7946,00 & 5 & 402,00 \\
\hline 8 & 8000,00 & 96000,00 & 8084,00 & 9026,00 & 12 & 942,00 \\
\hline 9 & 9000,00 & 108000,00 & 9164,00 & 11186,00 & 22 & 2022,00 \\
\hline 10 & 10000,00 & 120000,00 & 10244,00 & 13346,00 & 30 & 3102,00 \\
\hline 11 & 10691,08 & 128293,00 & 10990,00 & $14839,00^{* *}$ & 35 & 3849,00 \\
\hline 12 & 11000,00 & 132000,00 & 11324,00 & 16026,00 & 42 & 4702,00 \\
\hline 13 & 12000,00 & 144000,00 & 12404,00 & 19866,00 & 60 & 7462,00 \\
\hline 14 & 13000,00 & 156000,00 & 13484,00 & 23706,00 & 76 & 10222,00 \\
\hline 15 & 14000,00 & 168000,00 & 14564,00 & 27546,00 & 89 & 12982,00 \\
\hline 16 & 14254,83 & 171058,00 & $14839,00^{* *}$ & 28524,00 & 92 & 13685,00 \\
\hline 17 & 15000,00 & 180000,00 & 16270,00 & 31386,00 & 93 & 15116,00 \\
\hline 18 & 16000,00 & 192000,00 & 18190,00 & 35226,00 & 94 & 17036,00 \\
\hline 19 & 17000,00 & 204000,00 & 20110,00 & 39066,00 & 94 & 18956,00 \\
\hline 20 & 18000,00 & 216000,00 & 22030,00 & 42906,00 & 95 & 20876,00 \\
\hline 21 & 19000,00 & 228000,00 & 23950,00 & 46746,00 & 95 & 22796,00 \\
\hline 22 & 20000,00 & 240000,00 & 25870,00 & 50586,00 & 96 & 24716,00 \\
\hline 23 & 30000,00 & 360000,00 & 45070,00 & 88986,00 & 97 & 43916,00 \\
\hline 24 & 40000,00 & 480000,00 & 64270,00 & 127386,00 & 98 & 63116,00 \\
\hline 25 & 50000,00 & 600000,00 & 83470,00 & 165786,00 & 99 & 82316,00 \\
\hline
\end{tabular}

*Roczny podatek należny od pozycji 1 do pozycji 15 w kolumnie 4 i od pozycji 1 do pozycji 10 w kolumnie 5 obliczono według pierwszego przedziału skali podatkowej zgodnie ze stawka $18 \%$. **Roczny podatek należny od pozycji 16 w kolumnie 4 i od pozycji 11 w kolumnie 5 obliczono według drugiego przedziału skali podatkowej zgodnie ze stawką $32 \%$.

${ }^{* * *}$ Przy obliczeniach nie uwzględniono składek na ubezpieczenia społeczne oraz składki na ubezpieczenie zdrowotne.

Źródło: Obliczenia własne z wykorzystaniem skali podatkowej obowiązującej w latach 2012-2015. 
skania przychodu, jak i po ich wprowadzeniu), będzie zobowiązany do obliczenia podatku należnego według stawki podatkowej $32 \%$ właściwej dla drugiego przedziału skali podatkowej. Dla tej grupy podatników wzrost podatku należnego po wprowadzeniu omawianych zmian w kosztach uzyskania przychodu dla praw autorskich i praw pokrewnych będzie największy, ale będzie on wzrastał $\mathrm{w}$ miarę uzyskiwania większych przychodów, od $92 \%$ dla przychodu rocznego w wysokości 171058 zł do 99\% dla przychodu rocznego w wysokości 600 tys. zł.

\section{Wypłata wynagrodzenia uzyskanego z praw autorskich i praw pokrewnych}

Twórcy, artyści, pracownicy naukowi i dziennikarze, którzy otrzymują wynagrodzenie jednorazowo, ale w odpowiednio dużej kwocie za wykonana prace, tracą najwięcej na wprowadzonych od 1 stycznia 2013 roku zmianach w stosowaniu kosztów uzyskania przychodu. Przedmiotową stratę ilustruje tabela 2 .

Twórca, artysta, naukowiec czy też dziennikarz, który otrzyma wynagrodzenie w wysokości 250 tys. zł za stworzenie określonego dzieła raz na pięć lat lub dwa razy na pięć lat, wykorzysta podwyższone koszty uzyskania przychodu tylko do wynagrodzenia nieprzekraczającego $85528 \mathrm{zł}$. Z kolei ten sam podmiot, który będzie otrzymywał wynagrodzenie za pracę w wysokości 50 tys. zł przez pięc lat, wykorzysta $50 \%$ uzyskania przychodu w pełni. W sytuacji gdy będzie otrzymywał wynagrodzenie w wysokości 250 tys. zł za stworzenie dzieła przez trzy lata w wysokości dwa razy 100 tys. zł i raz 50 tys. zł - dwa razy wykorzysta podwyższone koszty uzyskania przychodu tylko do wynagrodzenia nieprzekraczającego $85528 \mathrm{zł}$, raz wykorzysta je w pełni, natomiast w sytuacji otrzymania tego samego wynagrodzenia przez cztery lata w wysokości raz 100 tys. zł i trzy razy 50 tys. zł - raz wykorzysta podwyższone koszty uzyskania tylko do wynagrodzenia nieprzekraczajacego $85528 \mathrm{zł}$, trzy razy wykorzysta je w pełni.

Zmiana wprowadzająca limit stosowania preferencyjnych 50\% kosztów uzyskania przychodów do wysokości 42764 zł rocznie (połowę kwoty podstawy opodatkowania określonej w pierwszym przedziale skali podatkowej, tj. $85528 \mathrm{zł)}$ dotyka nie tylko tych twórców, artystów, naukowców i dziennikarzy, których roczne dochody przekraczają przedmiotowy limit, ale także tych, którzy zarabiają średniorocznie mniej, ale za to nieregularnie, np. w odstępach kilkuletnich. Jak wynika z tabeli 2, osoba zarabiająca 50 tys. zł rocznie w okresie pięciu kolejnych lat $\mathrm{z}$ tytułu umowy o dzieło i stosująca 50-procentowe koszty uzyskania przychodu na omawianej zmianie przepisów nie straciła, bo jej roczny dochód wyniósł 25 tys. zł, czyli nie przekroczył 85528 zł. Jeśli jednak ta sama osoba zarobi 
Tabela 2

Sposób wypłaty wynagrodzenia z praw autorskich i praw pokrewnych w latach 2013$-2017$

\begin{tabular}{|c|c|c|c|c|c|c|c|}
\hline $\begin{array}{c}\text { Wyszcze- } \\
\text { gólnienie } \\
\text { [zł] }\end{array}$ & 2013 & 2014 & 2015 & 2016 & 2017 & $\Sigma$ & $\begin{array}{c}\text { Udział } \\
\text { podatku } \\
\text { w docho- } \\
\text { dach } \\
\text { w latach } \\
2013-2017 \\
\text { [\%] }\end{array}$ \\
\hline $\begin{array}{l}\text { Roczny } \\
\text { przychód }\end{array}$ & 250000,00 & - & - & - & - & 250000,00 & \multirow[b]{2}{*}{21,51} \\
\hline $\begin{array}{l}\text { Roczny } \\
\text { podatek } \\
\text { należny }\end{array}$ & 53786,00 & - & - & - & - & 53786,00 & \\
\hline $\begin{array}{l}\text { Roczny } \\
\text { przychód }\end{array}$ & 100000,00 & - & - & 150000,00 & - & 250000,00 & \multirow[b]{2}{*}{12,51} \\
\hline $\begin{array}{l}\text { Roczny } \\
\text { podatek } \\
\text { należny }\end{array}$ & 9746,00 & - & - & 217896,00 & - & 31532,00 & \\
\hline $\begin{array}{l}\text { Roczny } \\
\text { przychód }\end{array}$ & 100000,00 & - & 100000,00 & - & 50000,00 & 250000,00 & \multirow[b]{2}{*}{9,37} \\
\hline $\begin{array}{l}\text { Roczny } \\
\text { podatek } \\
\text { należny }\end{array}$ & 9746,00 & - & 9746,00 & - & 3944,00 & 23436,00 & \\
\hline $\begin{array}{l}\text { Roczny } \\
\text { przychód }\end{array}$ & 100000,00 & & 50000,00 & 50000,00 & 50000,00 & 250000,00 & \multirow[b]{2}{*}{8,63} \\
\hline $\begin{array}{l}\text { Roczny } \\
\text { podatek } \\
\text { należny }\end{array}$ & 9746,00 & & 3944,00 & 3944,00 & 3944,00 & 21578,00 & \\
\hline $\begin{array}{l}\text { Roczny } \\
\text { przychód }\end{array}$ & 50000,00 & 50000,00 & 50000,00 & 50000,00 & 50000,00 & 250000,00 & \multirow[b]{2}{*}{7,89} \\
\hline $\begin{array}{l}\text { Roczny } \\
\text { podatek } \\
\text { należny }\end{array}$ & 3944,00 & 3944,00 & 3944,00 & 3944,00 & 3944,00 & 19720,00 & \\
\hline
\end{tabular}

Źródło: Obliczenia własne z wykorzystaniem skali podatkowej obowiązującej w latach 2013_ $-2017$.

250 tys. zł rocznie z tytułu umowy o dzieło w ciagu jednego roku, nie może zastosować kosztów uzyskania przychodu do dochodów przekraczających kwotę limitu, czyli do dochodów wysokości 164472 zł.

Należy też zauważyć, że udział podatku dochodowego w dochodach zmienia się w zależności od tego, czy osoba otrzymuje wynagrodzenie za ukończone dzieło jednorazowo, czy sukcesywnie, np. za wykonanie części dzieła, dwa, trzy lub cztery razy w okresie pięciu lat. W sytuacji otrzymania jednorazowego wynagrodzenia udział podatku dochodowego w dochodach wynosi $21,51 \%$, obniża 
się aż o 9 punktów procentowych w sytuacji gdy wynagrodzenie za stworzenie dzieła jest wypłacone w okresie dwóch lat, następnie obniża się o ponad 12 punktów procentowych, gdy wynagrodzenie jest wypłacane w okresie trzech lat, o blisko 13 punktów procentowych, gdy wynagrodzenie jest wypłacane w okresie czterech lat, i tylko o niecałe 5 punktów procentowych, gdy wynagrodzenie jest wypłacane przez pięć lat.

Przeprowadzone rozważania pozwalają na stwierdzenie, że wprowadzenie limitu w zakresie stosowania kosztów uzyskania przychodu najdotkliwiej odczują najbogatsi twórcy, artyści, naukowcy i dziennikarze, w tym ci, którzy osiagną $\mathrm{z}$ tego tytułu jednorazowe wynagrodzenie przekraczające $85528 \mathrm{zł}$ po ukończeniu dzieła. Prowadzi to do wniosku, że jeśli praca nad utworem (dziełem) będzie trwała dłużej niż rok, a końcowy przychód przekroczy kwotę 85528 zł warto zastanowić się nad częściowym rozliczeniem wykonywanych czynności w każdym roku pracy nad utworem (dziełem).

\section{Ocena danych empirycznych dotyczących przychodów z praw autorskich i praw pokrewnych w kontekście budżetu państwa}

Ministerstwo Finansów, uzasadniając cel wprowadzenia rocznego limitu kwotowego w wysokości 42764 zł w zakresie stosowania kosztów uzyskania przychodu w odniesieniu do przychodów podatnika z praw autorskich i praw pokrewnych, powoływało się na zwiększenie dochodów budżetu państwa w wysokości $164 \mathrm{mln}$ zł. Analizując dane empiryczne zawarte w informacjach Departamentu Podatków Dochodowych o rozliczeniach podatku dochodowego przez osóby fizyczne [Informacja dotyczqca rozliczenia podatku dochodowego od osób fizycznych za 2012 rok, nformacja dotyczqca rozliczenia podatku dochodowego od osób fizycznych za $2013 \mathrm{rok}]^{9}$, nie można stwierdzić, iż przyjęta regulacja faktycznie spowodowała wpływy do budżetu państwa w przewidywanej wysokości. Analizując te dane, należy stwierdzić, że:

- biorąc pod uwagę liczbę podatników, którzy uzyskali przychody wyłącznie z jednego źródła - z praw autorskich i praw pokrewnych - w 2013 roku w porównaniu z rokiem poprzednim zwiększyła się ona o 8393 podatników, z kolei dochody tych podatników w 2013 roku w porównaniu z rokiem poprzednim zmniejszyły się o 12031 tys. zł, przy czym dochody z pozarolniczej działalności gospodarczej wzrosły w 2013 roku w porównaniu z rokiem poprzednim o 2799782 tys. zł,

\footnotetext{
${ }^{9} \mathrm{Na}$ dzień przygotowania niniejszej publikacji brak dostępnych danych za lata 2014-2015.
} 
- liczba podatników, którzy rozliczyli się z fiskusem, składając zeznanie na formularz PIT-36L, czyli tych podatników, którzy uzyskali dochody z pozarolniczej działalności gospodarczej opodatkowanej według zasad ogólnych według stawki liniowej 19\%, wzrosła w 2013 roku w porównaniu z rokiem poprzednim o 4,05\% (z 429096 podatników w 2012 roku do 446485 podatników w 2013 roku).

Spowodowane jest to niewątpliwie tym, że w obronie przed znacząco rosnącym podatkiem dochodowym od osób fizycznych, twórcy, artyści, naukowcy czy dziennikarze osiaggający rocznie przychody powyżej 85528 zł zdecydowali się na prowadzenie działalności twórczej w ramach pozarolniczej działalności gospodarczej opodatkowanej według stawki liniowej 19\%, co ważne z możliwością odliczenia do $100 \%$ kosztów uzyskania przychodu, a nie tak jak w ramach umowy o dzieło do wysokości 42764 zł. Tylko jeśli ta grupa podatników zdecyduje się na wykonywanie pozarolniczej działalności gospodarczej, będzie to związane z utrudnieniami, z jakimi będą musieli się zmierzyć - zamiast oddać się w 100\% działalności twórczej, artystycznej, naukowej czy dziennikarskiej będą musieli: poświęcić czas na założenie firmy, prowadzenie dokumentacji księgowej i realizację pozostałych obowiązków właściwych podmiotom gospodarczym. Prowadzenie przez tą grupę podatników pozarolniczej działalności gospodarczej wywoła także skutki dla funkcjonowania systemu podatkowego i organów podatkowych. Organy podatkowe, zobligowane do właściwego nadzoru i kontroli działalności podmiotów gospodarczych, będą musiały realizować swoje obowiązki również w stosunku do tej grupy społecznej, co niewątpliwie zwiększy koszt ich funkcjonowania.

Tabela 3 przedstawia liczbę podatników, którzy uzyskali przychody z praw autorskich i praw pokrewnych i dla których właściwym miejscowo do rozliczenia podatkowego za lata 2012-2015 był Urząd Skarbowy w Siedlcach, tabela 4 - liczbę podatników, którzy uzyskali przychody większe niż 85528 zł z praw autorskich i praw pokrewnych oraz średnią wysokość kosztów dla tej grupy podatników w 2012 roku, tabela 5 - wysokość podatku należnego zapłaconego z ww. źródła przychodów, a tabela 6 - wysokość przeciętnego przychodu, kosztów uzyskania przychodu oraz dochodu przypadającego na jednego podatnika osiagających przychody z praw autorskich i praw pokrewnych.

\section{Tabela 3}

Liczba podatników osiagających przychody z praw autorskich i praw pokrewnych

\begin{tabular}{|l|c|c|c|}
\hline Wyszczególnienie & 2012 & 2013 & 2014 \\
\hline Liczba podatników & 1436 & 1400 & 1374 \\
\hline
\end{tabular}

Źródło: Dane z systemu POLTAX Urzędu Skarbowego w Siedlcach. 


\section{Tabela 4}

Liczba podatników, którzy uzyskali przychody większe niż 85528 zł z praw autorskich i praw pokrewnych, oraz średnia wysokość kosztów dla tej grupy podatników w 2012 roku

\begin{tabular}{|l|c|c|c|}
\hline Wyszczególnienie & 2012 & 2013 & 2014 \\
\hline $\begin{array}{l}\text { Liczba podatników o przychodach } \\
\text { większych niż 85 528 zł }\end{array}$ & 19 & 7 & 3 \\
\hline $\begin{array}{l}\text { Średnie koszty dla tej grupy } \\
\text { podatników [zł] }\end{array}$ & 61631,50 & - & - \\
\hline
\end{tabular}

Źródło: Dane z systemu POLTAX Urzędu Skarbowego w Siedlcach.

\section{Tabela 5}

Podatek należny od podatników osiagających przychody z praw autorskich i praw pokrewnych

\begin{tabular}{|l|c|c|c|}
\hline Wyszczególnienie & 2012 & 2013 & 2014 \\
\hline Podatek należny [zł] & 1082291,00 & 910337,00 & 997629,00 \\
\hline
\end{tabular}

Źródło: Dane z systemu POLTAX Urzędu Skarbowego w Siedlcach.

\section{Tabela 6}

Przeciętne przychody, koszty uzyskania przychodu oraz dochód przypadający na jednego podatnika osiagającego przychody z praw autorskich i praw pokrewnych

\begin{tabular}{|l|c|c|c|}
\hline Wyszczególnienie [zł] & 2012 & 2013 & 2014 \\
\hline Przychód & 8692,75 & 7247,51 & 7974,68 \\
\hline Koszty uzyskania przychodu & 4346,38 & $3313,08^{*}$ & $3634,20^{* *}$ \\
\hline Dochód & 4346,38 & 3934,43 & 4340,48 \\
\hline
\end{tabular}

*W 2013 roku 19 podatników było zobowiazanych do zastosowania limitu kosztów uzyskania przychodu w wysokości 42764 zł.

**W 2014 roku 8 podatników było zobowiazanych do zastosowania limitu kosztów uzyskania przychodu w wysokości 42764 zł.

Źródło: Dane z systemu POLTAX Urzędu Skarbowego w Siedlcach.

Analizując dane empiryczne zawarte w tych tabelach, należy stwierdzić, że:

- liczba podatników, którzy uzyskali przychody z praw autorskich i innych praw, zmniejszała się sukcesywnie w analizowanych latach 2012-2014, w 2013 roku w porównaniu z rokiem poprzednim zmniejszyła się o 36 podatników, a w 2014 roku w porównaniu z rokiem poprzednim o 26 podatników,

- liczba podatników, którzy uzyskali przychody z praw autorskich i praw pokrewnych większe niż 85528 zł w 2012 roku, wynosiła 19, w latach 2013 i 2014 zmniejszyła się o odpowiednio ponad 63\% (7 podatników) i ponad $84 \%$ (3 podatników), 
- przeciętne przychody, koszty uzyskania przychodu oraz dochód przypadający na jednego podatnika osiagającego przychody z praw autorskich i praw pokrewnych kształtował się na zbliżonym poziomie,

- podatek należny odprowadzony do budżetu państwa z omawianego źródła przychodów nie zwiększył się w 2013 roku w porównaniu z rokiem poprzednim, wręcz przeciwnie był mniejszy o 171954 zł, tj. o blisko $16 \%$, a w 2014 roku kształtował się na porównywalnym poziomie co w roku poprzednim (zwiększył się o ok. 9\%).

Zatem należy zauważyć, że wprowadzenie limitu zastosowania kosztów uzyskania przychodu z praw autorskich i praw pokrewnych, biorąc pod uwage twórców, artystów i pracowników naukowych objętych właściwością miejscową Urzędu Skarbowego w Siedlcach, nie spowodowało zwiększenia wpływów do budżetu państwa. Nastąpił wręcz realny spadek dochodów budżetowych z tego tytułu w 2013 roku. Zaplanowany przez Ministerstwo Finansów wzrost wpływów do budżetu państwa $\mathrm{z}$ tytułu omawianych w artykule zmian nie przyniósł oczekiwanych rezultatów. Stał się on jedynie dodatkowym instrumentem obniżającym przychody autorów pozbawionych w większości stałych miesięcznych przychodów ze stosunku pracy, uzyskujących często wynagrodzenie raz w roku lub raz na kilka lat w zależności od rodzaju twórczości. Przychody z pracy autorskiej są nieregularne, niepewne, często wypłacane z dużym opóźnieniem w stosunku do czasu wykonania zamówionego dzieła. Często przychody te maleją lub nikną całkowicie po krótkich okresach osiagania największych przychodów. W dłuższej perspektywie czasowej niemal nigdy nie są regularne ani pewne.

Bez zawodów twórczych i ich znacznej roli w społeczeństwie i gospodarce nie będzie wzrostu dochodu narodowego i rozwoju gospodarczego. Zarówno wiedza, innowacje, wynalazczość, jak i twórczość kulturalna powinny mieć rosnące znaczenie w gospodarce. Państwu polskiemu powinno zależeć na tworzeniu warunków do wspierania wzrostu gospodarczego i rozwoju społecznego poprzez zwiększanie skali przychodów i dochodów z wszelkich form osobiście wykonywanej pracy twórczej, a nie na ich ograniczaniu, i to wyłącznie po to, żeby osiaggać prognozowane korzyści budżetowe, a nie realne w postaci zwiększenia w ten sposób wpływów podatkowych do budżetu państwa. Wprowadzenie przedmiotowych zmian nie ma zatem żadnego faktycznego i racjonalnego uzasadnienia. Ograniczenie odliczenia 50\% kosztów uzyskania przychodu do wysokości 42764 zł podjęte zostało bez uwzględnienia specyfiki działalności twórczej, artystycznej, naukowej czy dziennikarskiej, która wymaga szczególnego nakładu własnej pracy, innych, czasami bardzo dużych nakładów materialnych i niematerialnych, czasu potrzebnego na osiagnnięcie efektu twórczej inspiracji, który niejednokrotnie mierzony jest $\mathrm{w}$ miesiącach, a nawet latach. Ponadto 
należy dodać, że polscy twórcy, artyści, naukowcy czy dziennikarze najczęściej nie stanowią grupy społecznej o największych przychodach, a zatem nie powinna to być grupa społeczna, która ma ponosić koszty poprawy stanu finansów publicznych.

\section{Podsumowanie}

Należy stwierdzić, że zmiana dotycząca stosowania kosztów uzyskania przychodu przez twórców, artystów, pracowników naukowych i dziennikarzy wprowadzona od 1 stycznia 2013 roku jest niezasadna i przyczynia się do pogorszenia ich sytuacji materialnej. Zniechęca tę grupę społeczną do prowadzenia działalności twórczej bez względu na dziedzinę oraz zniechęca ją do angażowania się w działalność artystyczną, naukową i kulturalną.

Państwo polskie powinno aktywnie wspierać wszelkie formy pracy twórczej i jej kreatywne rezultaty, jeśli chcemy rozwijać naszą gospodarkę i zaspokajać potrzeby społeczne za pomocą tworzenia dóbr niematerialnych, nie zaś wprowadzać antymotywacyjne ograniczenia w postaci limitowanych do kwoty 42764 zł 50\% kosztów uzyskania przychodu ograniczających w ten sposób dochody z działalności twórczej osób o szczególnych predyspozycjach, talentach, kwalifikacjach i umiejętnościach, których rezultaty pracy służą w różny sposób ogólnemu pożytkowi publicznemu. Postęp i rozwój oraz ich dynamika zależą od rozwoju, wiedzy i pracy twórczej, a także od twórczości kulturalnej, są to istotne czynniki obrony przed skutkami kryzysu i wychodzenia z niego.

\section{Literatura}

BARTOSIEWICZ A., KUBACKI R., 2013: PIT. Komentarz, Wolters Kluwer Polska, Warszawa.

Informacja dotyczqca rozliczenia podatku dochodowego od osób fizycznych za 2012 rok, 2013. Departament Podatków Dochodowych, Warszawa.

Informacja dotyczqca rozliczenia podatku dochodowego od osób fizycznych za 2013 rok, 2014. Departament Podatków Dochodowych, Warszawa.

RADWAŃSKI Z. (red.) 2007: Prawo autorskie. System prawa prywatnego, tom 13, wydanie 2, C.H. Beck, Warszawa.

Ustawa z dnia 4 lutego 1997 r. o prawie autorskim i prawach pokrewnych (Dz.U. 1997 nr 24, poz. 83 ze zm.).

Ustawa z dnia 24 października 2012 r. o zmianie podatku dochodowego od osób fizycznych (Dz.U. 2012, poz. 1278). 
Ustawa z dnia 26 lipca 1991 r. o podatku dochodowym od osób fizycznych (tekst jednolity Dz.U. 2012, poz. 361 ze zm.).

Wyrok NSA z 12.03.2010 r. II FSK 17914/08.

Wyrok WSA w Gliwicach z 11.01.2011 r. I SA/Gl 781/10.

Wyrok WSA w Krakowie z 16.02.2010 r. I SA/Kr 1454/09.

Wyrok WSA w Warszawie z 3.07.2009 r. III SA/Wa 35/09.

\section{Abstrakt}

W opracowaniu przedstawiono ocenę skutków zmian stosowania kosztów uzyskania przychodów przez twórców, artystów, pracowników naukowych i dziennikarzy z tytułu praw autorskich i praw pokrewnych, które polegały na wprowadzeniu od 1 stycznia 2013 roku limitu kwotowego 42764 zł. Realizacji celu opracowania posłużono się: (1) analizą danych pochodzących z opracowań Ministerstwa Finansów dotyczących rozliczenia podatku dochodowego od osób fizycznych za lata 2012-2013, jak również analizą danych z systemu POLTAX Urzędu Skarbowego w Siedlcach dotyczących rozliczenia podatku dochodowego od osób fizycznych za lata 2012-2015 oraz (2) komentarzem do wprowadzonych zmian stosowania kosztów uzyskania przychodów przez twórców, artystów, pracowników naukowych i dziennikarzy.

Po przeprowadzonej analizie oraz rozważaniach stwierdzono, że przedmiotowe zmiany dotyczące stosowania kosztów uzyskania przychodów przez omawianą grupę podatników ograniczają ich dochody i działają antymotywacyjnie na ich aktywność zawodową.

Slowa kluczowe: podatek dochodowy od osób fizycznych, 50\% koszty uzyskania przychodów, prawa autorskie i prawa pokrewne

\section{The evaluation of the results of changes in applying tax deductible expenses by artists, academic workers and journalists}

\section{Abstract}

The paper contains of evaluation of the results of changes in applying tax deductible expenses by artists, academic workers and journalists as copyrights and related rights-holders resulting from the limit of 42,764 PLN introduced on 1 January 2013. The research was based on: (i) the analysis of data from the Ministry of Finance regarding personal income tax settlement in 2012-2013, 
as well as the analysis of the data from POLTAX system from Urząd Skarbowy w Siedlcach (eng. Tax Office in Siedlce) regarding personal income tax settlement in 2012-2015 and (ii) the commentary of artists, academic workers and journalists regarding the abovementioned changes.

The analysis indicated that changes in applying tax deductible revenues by the group of taxpayers in question hinders their revenues and has an anti-motivational influence on their professional activity.

Key words: personal income tax, $50 \%$ income costs, copyrights and related rights 